\title{
Binding Strength of Nucleobases and Nucleosides on Silver Nanoparticles Probed by a Colorimetric Method
}

$\mathrm{Lu} \mathrm{Yu}$, and $\mathrm{Na} \mathrm{Li}^{*}$

Department of Mechanical and Aerospace Engineering, University of Miami, Coral Gables, Florida, 33146, United States

SUPPORTING INFORMATION 


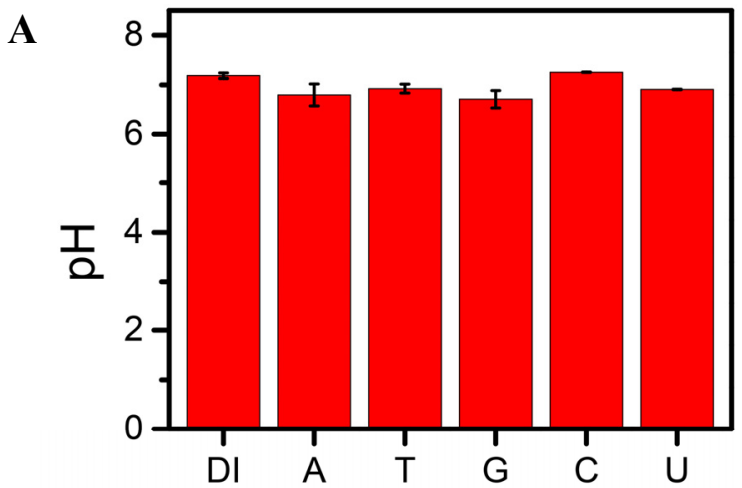

\section{Nucleobases}

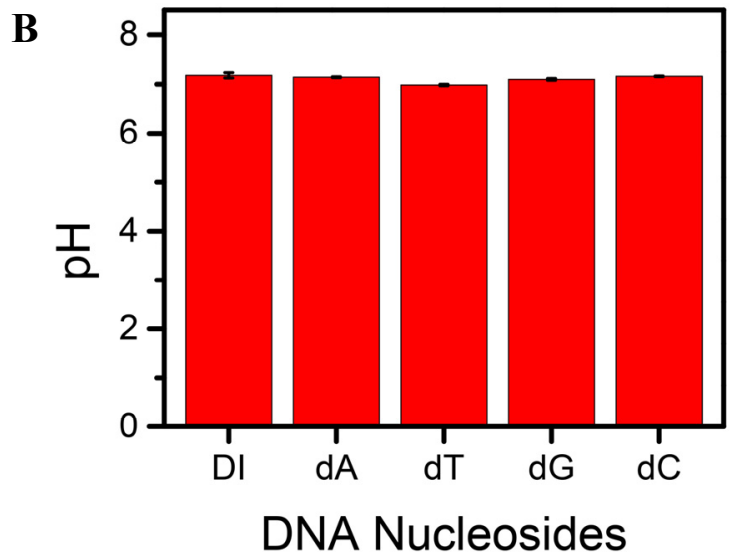

C

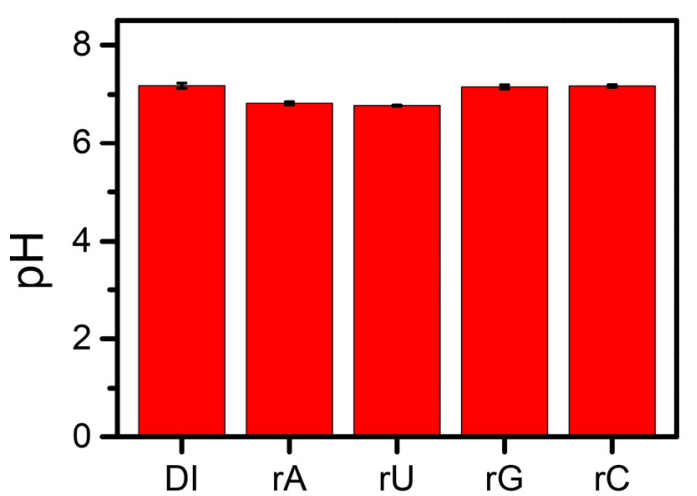

RNA Nucleosides

Figure S1. $\mathrm{pH}$ of mixtures of AgNPs with high concentrations of (A) nucleobases, (B) DNA nucleosides, and (C) RNA nucleosides. The concentrations of nucleobases used were as follows: $\mathrm{A}(10 \mathrm{mM}), \mathrm{T}(20 \mathrm{mM}), \mathrm{G}(20 \mathrm{mM}), \mathrm{C}(60 \mathrm{mM})$, and $\mathrm{U}(20 \mathrm{mM})$. The concentrations of DNA 
nucleosides used were as follows: dA(40 mM), dT(160 mM), dG(15 mM), dC(150 mM). The concentrations of RNA used were as follows: rA(60 mM), rU(800 mM), rG(30 mM), rC(500 $\mathrm{mM})$. The deionized water was used as a control. 

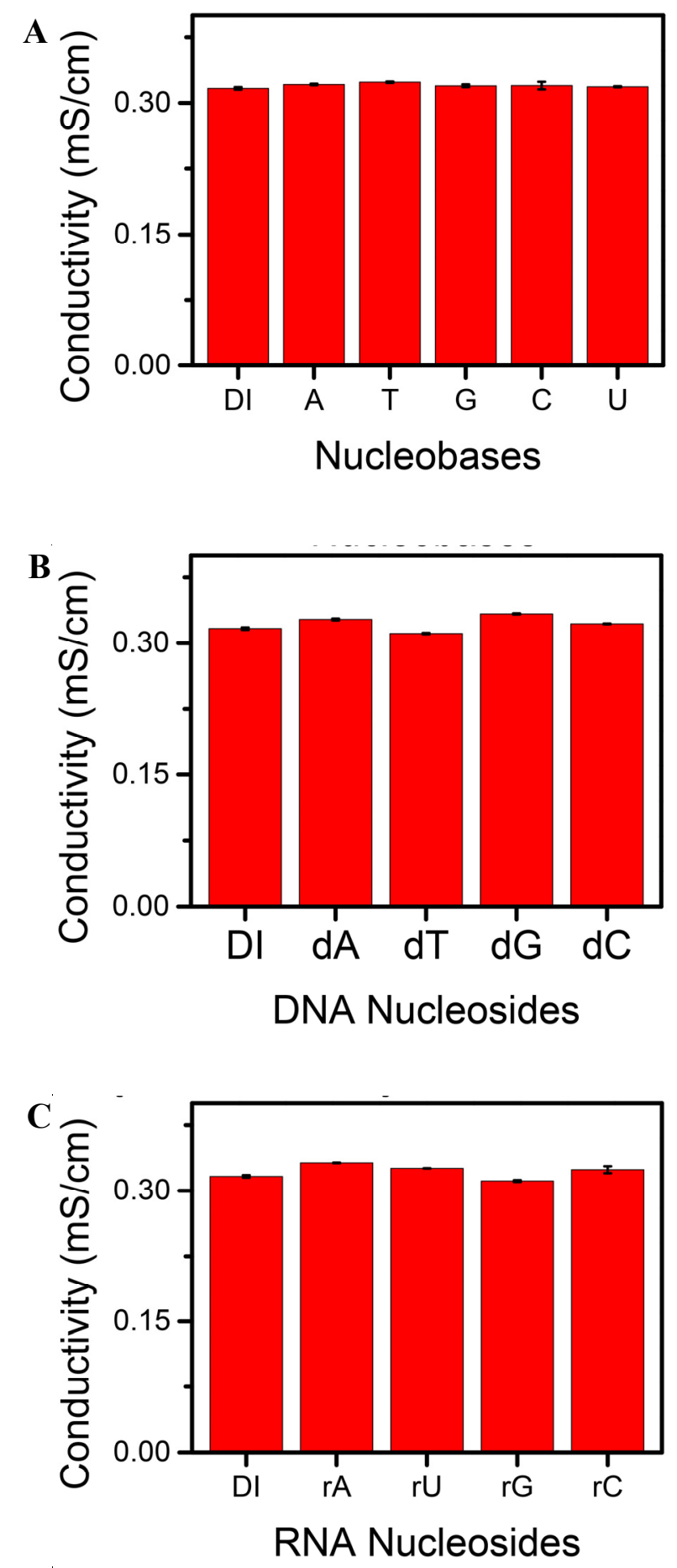

Figure S2 Conductivity of mixtures of AgNPs high concentrations of (A) nucleobases, (B) DNA nucleosides, and (C) RNA nucleosides. The concentrations of nucleobases used were as follows: $\mathrm{A}(10 \mathrm{mM}), \mathrm{T}(20 \mathrm{mM}), \mathrm{G}(20 \mathrm{mM}), \mathrm{C}(60 \mathrm{mM})$, and $\mathrm{U}(20 \mathrm{mM})$. The concentrations of DNA 
nucleosides used were as follows: $\mathrm{dA}(40 \mathrm{mM}), \mathrm{dT}(160 \mathrm{mM}), \mathrm{dG}(15 \mathrm{mM}), \mathrm{dC}(150 \mathrm{mM})$. The concentrations of RNA used were as follows: rA(60 mM), rU(800 mM), rG(30 mM), rC(500 $\mathrm{mM})$. The deionized water was used as a control. 

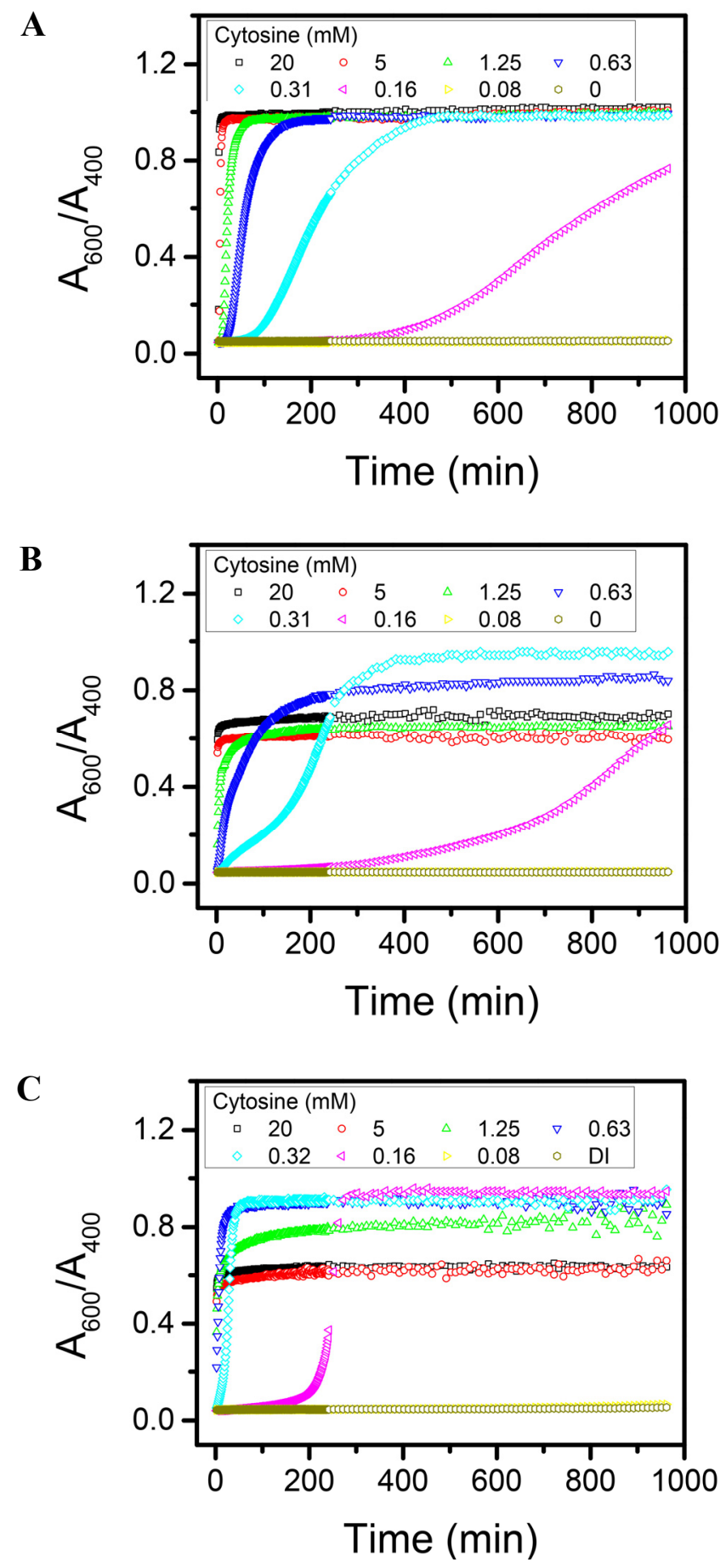

Figure S3. Effects of ion strength on the colorimetric changes of AgNPs induced by cytosine: (A) $0 \mathrm{mM}$, (B) $10 \mathrm{mM}$, and (C) $30 \mathrm{mM} \mathrm{NaCl}$. Cytosine dilution containing $\mathrm{NaCl}$ of different concentrations was mixed with AgNPs in equal volume ratio. 
A

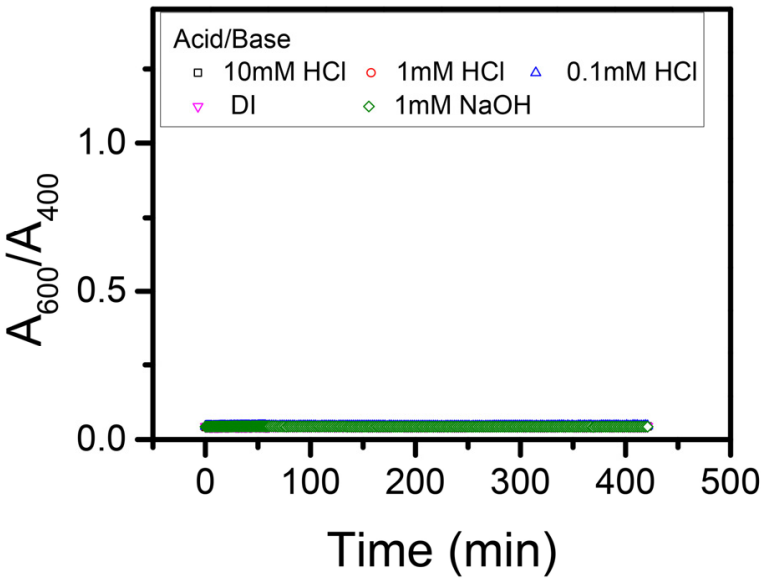

B

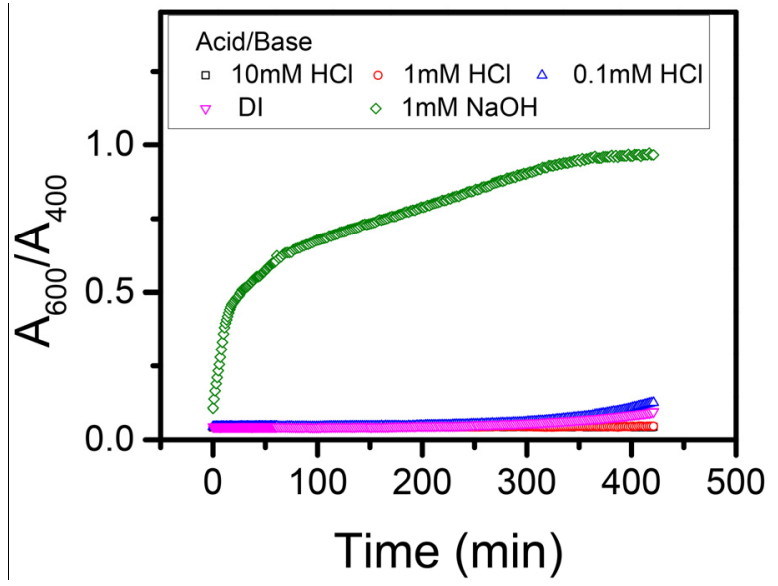

C

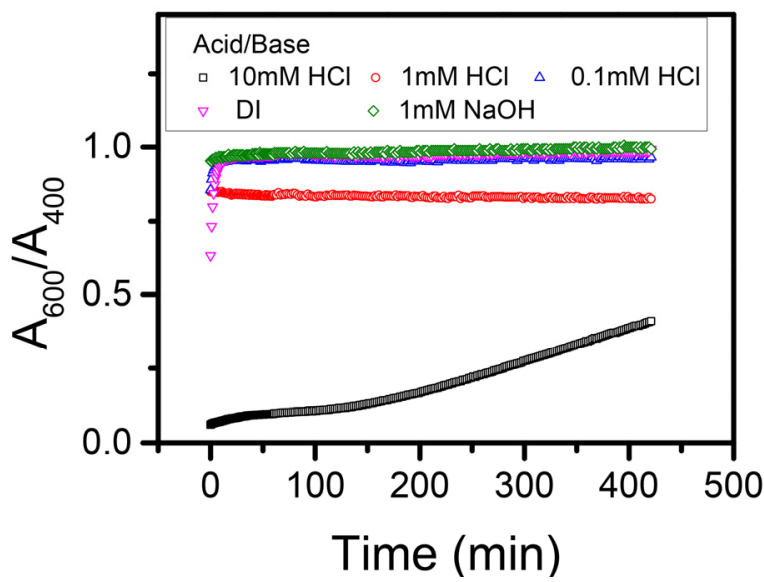

Figure S4. Effects of $\mathrm{pH}$ on the colorimetric changes of AgNPs induced by cytosine: (A) $0 \mathrm{mM}$, (B) $0.3125 \mathrm{mM}$, and (C) $5 \mathrm{mM}$ cytosine. Cytosine was mixed in equal volume ratio with $\mathrm{HCl}$ or $\mathrm{NaOH}$ before mixing with AgNPs in equal volume ratio. 